\title{
Effect of methanogenic substrates on anaerobic oxidation of methane and sulfate reduction by an anaerobic methanotrophic enrichment
}

\author{
Roel J. W. Meulepas • Christian G. Jagersma • \\ Ahmad F. Khadem • Alfons J. M. Stams • \\ Piet N. L. Lens
}

\begin{abstract}
Received: 16 February 2010 /Revised: 31 March 2010 / Accepted: 31 March 2010 /Published online: 6 May 2010
\end{abstract}
(C) The Author(s) 2010. This article is published with open access at Springerlink.com

\begin{abstract}
Anaerobic oxidation of methane (AOM) coupled to sulfate reduction (SR) is assumed to be a syntrophic process, in which methanotrophic archaea produce an interspecies electron carrier (IEC), which is subsequently utilized by sulfate-reducing bacteria. In this paper, six methanogenic substrates are tested as candidate-IECs by assessing their effect on AOM and SR by an anaerobic methanotrophic enrichment. The presence of acetate, formate or hydrogen enhanced SR, but did not inhibit $\mathrm{AOM}$, nor did these substrates trigger methanogenesis. Carbon monoxide also enhanced SR but slightly inhibited AOM. Methanol did not enhance SR nor did it inhibit $\mathrm{AOM}$, and methanethiol inhibited both SR and AOM completely. Subsequently, it was calculated at which candidate-IEC concentrations no more Gibbs free energy can be conserved from their production from methane at the
\end{abstract}

R. J. W. Meulepas $(\bowtie) \cdot$ P. N. L. Lens

Pollution Prevention and Control Core, UNESCO-IHE,

Westvest 7,

2611 AX Delft, The Netherlands

e-mail: r.meulepas@unesco-ihe.org

R. J. W. Meulepas • P. N. L. Lens

Sub-department of Environmental Technology,

Wageningen University,

Bomenweg 2, $6703 \mathrm{HD}$, Wageningen,

The Netherlands

C. G. Jagersma • A. J. M. Stams

Laboratory of Microbiology, Wageningen University,

Dreijenplein 10,

6703 HB Wageningen, The Netherlands

\section{A. F. Khadem}

Department of Microbiology, Radboud University Nijmegen,

Heyendaalseweg 135,

6525 AJ Nijmegen, The Netherlands applied conditions. These concentrations were at least 1,000 times lower can the final candidate-IEC concentration in the bulk liquid. Therefore, the tested candidate-IECs could not have been produced from methane during the incubations. Hence, acetate, formate, methanol, carbon monoxide, and hydrogen can be excluded as sole IEC in AOM coupled to SR. Methanethiol did inhibit AOM and can therefore not be excluded as IEC by this study.

Keywords Anaerobic oxidation of methane .

Interspecies electron carrier - Methanogenic substrates

\section{Introduction}

Anaerobic oxidation of methane (AOM) coupled to sulfate reduction (SR) according to Eq. 1, is an important process in the global carbon cycle (Hinrichs and Boetius 2002). The process was discovered during geochemical studies in marine sediments (Martens and Berner 1974; Barnes and Goldberg 1976; Reeburgh 1976).

$\mathrm{CH}_{4}+\mathrm{SO}_{4}{ }^{2-} \rightarrow \mathrm{HCO}_{3}{ }^{-}+\mathrm{HS}^{-}+\mathrm{H}_{2} \mathrm{O} \quad \Delta \mathrm{G}^{\mathrm{o},}=-16.6 \mathrm{~kJ} \cdot \mathrm{mol}^{-1}$

Phylogenetic analysis of AOM-SR sediments identified three novel groups of archaea putative called anaerobic methanotrophs (ANME); ANME-1, ANME-2, and ANME3. These ANME are distantly related to cultivated methanogenic members from the orders Methanosarcinales and Methanomicrobiales (Hinrichs et al. 1999; Orphan et al. 2002; Knittel et al. 2005; Niemann et al. 2006). Orphan et al. (2001, 2002) showed that cells belonging to ANME-1 and ANME-2 assimilated carbon from methane $\left(\mathrm{CH}_{4}\right)$ during AOM. ANME probably mediate a form of reversed methano- 
genesis since AOM, like methanogenesis, is inhibited by bromoethanesulfonate (Nauhaus et al. 2005); an analogue of the methyl-coenzyme $\mathrm{M}$ reductase was found to make up 7\% of the extracted soluble proteins from an AOM-mediating microbial mat from the Black Sea (Krüger et al. 2003), and ANME-1 cells were found to contain most of the genes typically associated with $\mathrm{CH}_{4}$ production (Hallam et al. 2003, 2004; Meyerdierks et al. 2010). Moreover, methanogens (Zehnder and Brock 1980; Harder 1997; Moran et al. 2007) and methanogenic sludge (Meulepas et al. 2010) also mediate $\mathrm{CH}_{4}$ oxidation, however during net methanogenesis.

No gene analogues for enzymes involved in dissimilatory SR were found in archaea belonging to ANME groups (Thauer and Shima 2008; Meyerdierks et al. 2010) and FISH techniques showed that ANME occur in aggregates (Boetius et al. 2000; Michaelis et al. 2002; Knittel et al. 2005) with bacteria related to Desulfosarcina-Desulfococcus or Desulfobulbus. These findings suggest that AOM coupled to SR is a syntrophic process, in which ANME convert $\mathrm{CH}_{4}$ to a metabolite which forms the electron donor for the sulfate-reducing bacterial (SRB) partner.

Given the evidence for reversed methanogenesis, methanogenic substrates have been proposed to act as interspecies electron carrier (IEC) (Hoehler et al. 1994; DeLong 2000). The standard Gibbs free energy change at $\mathrm{pH} 7\left(\Delta \mathrm{G}^{\circ}\right)$ of the production of these IECs from $\mathrm{CH}_{4}$ is positive (Table 1), but when the IEC concentration is kept low enough by the sulfate-reducing partner, the Gibbs free energy change will be negative. However, the SR activity of Hydrate Ridge sediment with hydrogen, formate, acetate, methanol, carbon monoxide, and methylamines was lower than SR activity on $\mathrm{CH}_{4}$, indicating that SRB involved in AOM, were not adapted to these substrates (Nauhaus et al. 2002, 2005). Wegener (2008) showed that the bacterial partners mainly assimilated inorganic carbon, which makes the uptake of an organic IEC less likely. Sørensen et al. (2001) excluded hydrogen, acetate, and methanol as IEC because the maximum diffusion distances of those compounds at in situ concentrations and rates were smaller than the thickness of two prokaryotic cell walls. Orcutt and Meile (2008) showed with process-based modeling that hydrogen and formate could not be exchanged fast enough between syntrophic partners to sustain the sulfate reduction rates found by Nauhaus et al. (2007), but for acetate this might be possible. Using a spherical diffusion-reaction model Alperin and Hoehler (2009) concluded that hydrogen, formate, and acetate are thermodynamically and physically possible intermediates in AOM coupled to SR.

This study presents a novel approach to investigate whether a compound acts as IEC. Firstly, the effect of the presence of candidate-IECs, at relative high concentrations, on AOM and SR by an enrichment, of ANME-2a and bacteria mainly belonging to Deltaproteobacteria and Flavobacteriales (Meulepas et al. 2009; Jagersma et al. 2009), is assessed. And secondly, the concentration of each candidate-IEC is calculated at which no more energy can be obtained from their production from $\mathrm{CH}_{4}$. If $\mathrm{AOM}$ still occurs at IEC concentrations far above this theoretical maximum, the AOM does not proceed via the production of that particular IEC. Due to the high AOM and SR activity of the enrichment $\left(0.2 \mathrm{mmol} \mathrm{L}^{-1}\right.$ day $\left.^{-1}\right)$, the effect of these additives can be assessed within a period of 4 days.

\section{Material and methods}

\section{Inoculate}

The biomass used for this research was taken from a 1-L submersed-membrane bioreactor, inoculated with $10 \mathrm{~g}$ dry weight Eckernförde Bay sediment (Baltic Sea), operated at

Table 1 The production and consumption of candidate interspecies electron carriers (IECs) in AOM coupled to SR

\begin{tabular}{|c|c|c|c|}
\hline Candidate-IEC & Potential subconversions in AOM coupled to SR & & \\
\hline \multirow[t]{2}{*}{ Acetate } & $\mathrm{CH}_{4}+\mathrm{HCO}_{3}^{-} \rightarrow \mathrm{CH}_{3} \mathrm{COO}^{-}+\mathrm{H}_{2} \mathrm{O}$ & $\Delta G^{\mathrm{o}}{ }_{\text {IEC production }}$ & $+31 \mathrm{~kJ} \mathrm{~mol}^{-1} \mathrm{CH}_{4}$ \\
\hline & $\mathrm{CH}_{3} \mathrm{COO}^{-}+\mathrm{SO}_{4}{ }^{2-} \rightarrow \mathrm{HS}^{-}+2 \mathrm{HCO}_{3}^{-}$ & $\Delta G^{\mathrm{o}}{ }_{\mathrm{IEC}}$ consumption & $-47 \mathrm{~kJ} \mathrm{~mol}^{-1} \mathrm{SO}_{4}{ }^{2-}$ \\
\hline \multirow[t]{2}{*}{ Formate } & $\mathrm{CH}_{4}+3 \mathrm{HCO}_{3}^{-} \rightarrow 4 \mathrm{HCO}_{2}^{-}+\mathrm{H}^{+}+\mathrm{H}_{2} \mathrm{O}$ & $\Delta G^{\mathrm{o}}{ }_{\text {IEC production }}$ & $+128 \mathrm{~kJ} \mathrm{~mol}^{-1} \mathrm{CH}_{4}$ \\
\hline & $4 \mathrm{HCO}_{2}^{-}+\mathrm{SO}_{4}{ }^{2-}+\mathrm{H}^{+} \rightarrow \mathrm{HS}^{-}+4 \mathrm{HCO}_{3}^{-}$ & $\Delta G^{\mathrm{o}}{ }_{\text {IEC }}$ consumption & $-144 \mathrm{~kJ} \mathrm{~mol}^{-1} \mathrm{SO}_{4}{ }^{2-}$ \\
\hline \multirow[t]{2}{*}{ Methanol } & $\mathrm{CH}_{4}+{ }^{1} /{ }_{3} \mathrm{HCO}_{3}{ }^{-}+{ }^{1} / 3 \mathrm{H}^{+}+{ }^{1} /{ }_{3} \mathrm{H}_{2} \mathrm{O} \rightarrow{ }^{4} /{ }_{3} \mathrm{CH}_{3} \mathrm{OH}$ & $\Delta G^{\mathrm{o}}{ }_{\text {IEC production }}$ & $+104 \mathrm{~kJ} \mathrm{~mol}^{-1} \mathrm{CH}_{4}$ \\
\hline & ${ }^{4} /{ }_{3} \mathrm{CH}_{3} \mathrm{OH}+\mathrm{SO}_{4}{ }^{2-} \rightarrow \mathrm{HS}^{-}+{ }^{4} /{ }_{3} \mathrm{HCO}_{3}{ }^{-}+{ }^{1} /{ }_{3} \mathrm{H}^{+}+{ }^{4} /{ }_{3} \mathrm{H}_{2} \mathrm{O}$ & $\Delta G^{\mathrm{o}}{ }_{\text {IEC }}$ consumption & $-120 \mathrm{~kJ} \mathrm{~mol}^{-1} \mathrm{SO}_{4}{ }^{2-}$ \\
\hline \multirow[t]{2}{*}{ Carbon monoxide } & $\mathrm{CH}_{4}+3 \mathrm{HCO}_{3}^{-}+3 \mathrm{H}^{+} \rightarrow 4 \mathrm{CO}+5 \mathrm{H}_{2} \mathrm{O}$ & $\Delta G^{\mathrm{o}}{ }_{\text {IEC production }}$ & $+196 \mathrm{~kJ} \mathrm{~mol}^{-1} \mathrm{CH}_{4}$ \\
\hline & $4 \mathrm{CO}+\mathrm{SO}_{4}^{2-}+4 \mathrm{H}_{2} \mathrm{O} \rightarrow \mathrm{HS}^{-}+4 \mathrm{HCO}_{3}^{-}+3 \mathrm{H}^{+}$ & $\Delta G^{\mathrm{o}}{ }_{\text {IEC }}$ consumption & $-212 \mathrm{~kJ} \mathrm{~mol}^{-1} \mathrm{SO}_{4}{ }^{2-}$ \\
\hline \multirow[t]{2}{*}{ Methanethiol } & $\mathrm{CH}_{4}+{ }^{1} /{ }_{3} \mathrm{HCO}_{3}{ }^{-}+{ }^{5} /{ }_{3} \mathrm{H}^{+}+{ }^{4} / 3 \mathrm{HS}^{-} \rightarrow{ }^{4} /{ }_{3} \mathrm{H}_{3} \mathrm{CSH}+\mathrm{H}_{2} \mathrm{O}$ & $\Delta G^{\mathrm{o}}{ }_{\text {IEC production }}$ & $+55 \mathrm{~kJ} \quad \mathrm{~mol}^{-1} \mathrm{CH}_{4}$ \\
\hline & ${ }^{4} /{ }_{3} \mathrm{H}_{3} \mathrm{CSH}+\mathrm{SO}_{4}{ }^{2-} \rightarrow{ }^{7} /{ }_{3} \mathrm{HS}^{-}+{ }^{4} /{ }_{3} \mathrm{HCO}_{3}{ }^{-}+{ }^{5} / \mathrm{H}^{+}$ & $\Delta G^{\mathrm{o}}{ }_{\text {IEC }}$ consumption & $-71 \mathrm{~kJ} \mathrm{~mol}^{-1} \mathrm{SO}_{4}{ }^{2-}$ \\
\hline \multirow[t]{2}{*}{ Hydrogen } & $\mathrm{CH}_{4}+3 \mathrm{H}_{2} \mathrm{O} \rightarrow 4 \mathrm{H}_{2}+\mathrm{HCO}_{3}^{-}+\mathrm{H}^{+}$ & $\Delta G^{\mathrm{o}}{ }_{\text {IEC production }}$ & $+136 \mathrm{~kJ} \mathrm{~mol}^{-1} \mathrm{CH}_{4}$ \\
\hline & $4 \mathrm{H}_{2}+\mathrm{SO}_{4}^{-}+\mathrm{H}^{+} \rightarrow \mathrm{HS}^{-}+4 \mathrm{H}_{2} \mathrm{O}$ & $\Delta G^{\mathrm{o}}{ }_{\text {IEC }}$ consumption & $-152 \mathrm{~kJ} \mathrm{~mol}^{-1} \mathrm{SO}_{4}{ }^{2-}$ \\
\hline
\end{tabular}

The standard Gibbs free energy changes were obtained from Thauer et al. (1977) 
$15{ }^{\circ} \mathrm{C}$, sparged with $4.8 \mathrm{~L} \mathrm{~L}^{-1}$ day ${ }^{-1}$ pure $\mathrm{CH}_{4}$ gas and fed with $0.14 \mathrm{~L} \mathrm{~L} \mathrm{~L}^{-1}$ day $^{-1}$ marine medium. The basal medium consisted of: $\mathrm{NaCl}\left(19.8 \mathrm{~g} \mathrm{~L}^{-1}\right), \mathrm{KCl}\left(0.45 \mathrm{~g} \mathrm{~L}^{-1}\right)$, $\mathrm{MgCl}_{2} \cdot 6 \mathrm{H}_{2} \mathrm{O}\left(4.25 \mathrm{~g} \mathrm{~L}^{-1}\right), \mathrm{NH}_{4} \mathrm{Cl}\left(0.25 \mathrm{~g} \mathrm{~L}^{-1}\right)$, $\mathrm{CaCl}_{2} \cdot 2 \mathrm{H}_{2} \mathrm{O}\left(1.19 \mathrm{~g} \mathrm{~L}^{-1}\right), \mathrm{MgSO}_{4} \cdot 7 \mathrm{H}_{2} \mathrm{O}\left(5.10 \mathrm{~g} \mathrm{~L}^{-1}\right)$, $\mathrm{KH}_{2} \mathrm{PO}_{4}\left(0.34 \mathrm{~g} \mathrm{~L}^{-1}\right), \mathrm{K}_{2} \mathrm{HPO}_{4} \cdot 3 \mathrm{H}_{2} \mathrm{O}\left(1.25 \mathrm{~g} \mathrm{~L}^{-1}\right)$, a trace element solution $\left(1 \mathrm{~mL} \mathrm{~L}^{-1}\right)$, a vitamin solution $\left(1 \mathrm{~mL} \mathrm{~L}^{-1}\right)$, a $0.5 \mathrm{~g} \mathrm{~L}^{-1}$ resazurin solution $\left(1 \mathrm{~mL} \mathrm{~L}^{-1}\right)$, a $0.1 \mathrm{M} \mathrm{Na}_{2} \mathrm{~S}$ solution $\left(1 \mathrm{~mL} \mathrm{~L}^{-1}\right)$, and demineralized water. The trace elements and vitamin solutions were made according to Widdel and Bak (1992). The first 330 days, $70 \mu \mathrm{mol} \mathrm{L}^{-1}$ day $^{-1}$ acetate was supplied as cosubstrate, after that $\mathrm{CH}_{4}$ was the sole supplied electron donor and carbon source. During 884 days, the volumetric $\mathrm{AOM}$ rate increased exponentially from 0.002 to $0.6 \mathrm{mmol} \mathrm{L}^{-1} \mathrm{day}^{-1}$ (Meulepas et al. 2009). The biomass used for this research was sampled at day 584. To ensure homogeneous sampling, liquid recirculation $\left(0.5 \mathrm{~L} \mathrm{~min}^{-1}\right)$ and gas sparging $\left(2 \mathrm{~L} \mathrm{~min}^{-1}\right)$ were applied prior to and during sampling. Microbial analyses of the enrichment (clone library and fluorescent in situ hybridization) showed that the archaeal community was dominated by ANME-2a and that the bacterial community mainly consists of members of the Deltaproteobacteria and Bacteroidetes (Jagersma et al. 2009). During AOM, carbon derived from $\mathrm{CH}_{4}$ was incorporated in both archaeal and bacterial lipids (Jagersma et al. 2009).

\section{Incubations with candidate-IECs}

Experiments were done in $35-\mathrm{mL}$ serum bottles closed with butyl rubber stoppers and caps. After determining the exact weight and volume, the bottles were eluted with nitrogen gas. Subsequently, $30 \mathrm{~mL}$ undiluted reactor suspension was transferred from the bioreactor to the bottles by syringe. The reactor suspension contained $0.59 \mathrm{~g}$ volatile suspended solids per liter (a measure for the biomass content). The headspace of each bottle was evacuated again and replaced by $0.16( \pm 0.01) \mathrm{MPa}{ }^{13} \mathrm{C}$-labeled $\mathrm{CH}_{4}\left({ }^{13} \mathrm{CH}_{4}\right)$ with a purity of $99 \%$ from Campro (Veenendaal, The Netherlands). Subsequently, $1.0 \mathrm{mM}$ acetate, $1.0 \mathrm{mM}$ formate, $1.0 \mathrm{mM}$ methanol, $7.2 \mathrm{kPa}$ carbon monoxide, $1.0 \mathrm{mM}$ methanethiol, or $7.2 \mathrm{kPa}$ hydrogen were added as candidate-IECs from stock bottles. In addition, control incubations without IEC were done. Incubations were done in duplicate. However, one incubation with methanethiol and one with hydrogen had to be terminated before day 4 , due to leaking. These duplicates could not be repeated due to a limited biomass stock. The bottles were incubated at $15{ }^{\circ} \mathrm{C}$ and shaken in an orbital shaker at $100 \mathrm{rpm}$. The gas composition, $\mathrm{pH}$, and pressure were determined once or twice a day. The carbon monoxide and hydrogen fraction in the headspace, the sulfate and formate concentration, the dissolved sulfide concentration, and the concentration of fatty acids and alcohols were analyzed immediately after inoculation and after 4 days. Sampling was done at the incubation temperature $\left(15{ }^{\circ} \mathrm{C}\right)$.

\section{Analysis}

The headspace composition was measured on a gas chromatograph-mass spectrometer (GC-MS) from Interscience (Breda, The Netherlands). The system was composed of a Trace GC equipped with a GS-GasPro column ( $30 \mathrm{~m}$ by $0.32 \mathrm{~mm}$; J\&W Scientific, Folsom, CA, USA), and a Ion-Trap MS. Helium was the carrier gas at a flow rate of $1.7 \mathrm{~mL} \mathrm{~min}{ }^{-1}$. The column temperature was $30{ }^{\circ} \mathrm{C}$. The fractions of $\mathrm{CH}_{4}$ and $\mathrm{CO}_{2}$ in the headspace were derived from the peak areas in the gas chromatograph. The fractions of ${ }^{13} \mathrm{C}$-labeled $\mathrm{CH}_{4}\left({ }^{13} \mathrm{CH}_{4}\right)$ and ${ }^{13} \mathrm{C}$-labeled $\mathrm{CO}_{2}\left({ }^{13} \mathrm{CO} 2\right)$ were derived from the mass spectra as done by Shigematsu et al. (2004). The headspace pressure, sulfide concentration, and $\mathrm{pH}$ were analyzed as described by Meulepas et al. (2009). The sulfate concentration was analyzed according to Sipma et al. (2004), and the acetate and methanol concentration were analyzed according to Weijma et al. (2000). Formate was measured on a DX-600 IC system (Dionex Corporation, Salt Lake City, USA) equipped with IonPac AG17 and AS17 $4 \mathrm{~mm}$ columns, operated at a temperature of $30{ }^{\circ} \mathrm{C}$, and a flow rate of $1.5 \mathrm{~mL} \mathrm{~min}{ }^{-1}$. The injection volume was $25 \mu \mathrm{L}$. The eluent was made on-line using the EG40 Eluent Generator (Dionex) equipped with a $\mathrm{KOH}$ cartridge (Dionex P/N 053921) and deionized water as the carrier. Prior to analysis, samples were centrifuged and diluted 20 times. Hydrogen and carbon monoxide were measured on a gas chromatograph HP 5890 (Hewlett Packard, Palo Alto, USA) as described previously (Sipma et al. 2004). Methanethiol was measured on a HP 6890 gas chromatograph equipped with a Supelco sulfur SPB-1 column (Bellefonte, PA, USA) according to van den Bosch et al. (2009).

\section{Calculations}

The ${ }^{13} \mathrm{C}$-dissolved inorganic carbon $\left({ }^{13} \mathrm{C}\right.$-DIC, ${ }^{13} \mathrm{C}$-labeled $\mathrm{CO}_{2}$, and ${ }^{13} \mathrm{C}$-labeled bicarbonate) and ${ }^{12} \mathrm{C}$-DIC per bottle were calculated according to the equation given by Meulepas et al. (2009).

The concentration of each candidate-IEC at which no more energy can be obtained $\left(\Delta G_{\mathrm{IEC}}\right.$ production $\left.=0\right)$ from their production from $\mathrm{CH}_{4}$ (Table 1) was calculated. This is done according to Eq. 2.

$$
\Delta G_{\text {IEC_production }}=\Delta G_{\text {IEC_Production }}^{\circ}+R T \ln \frac{\prod[\text { products }]}{\prod[\text { substrates }]}
$$

$R \quad$ gas constant $=8.314 \mathrm{~J} \mathrm{~mol}^{-1} \mathrm{~K}^{-1}$

$T$ temperature in $K=288.15 \mathrm{~K}$ 

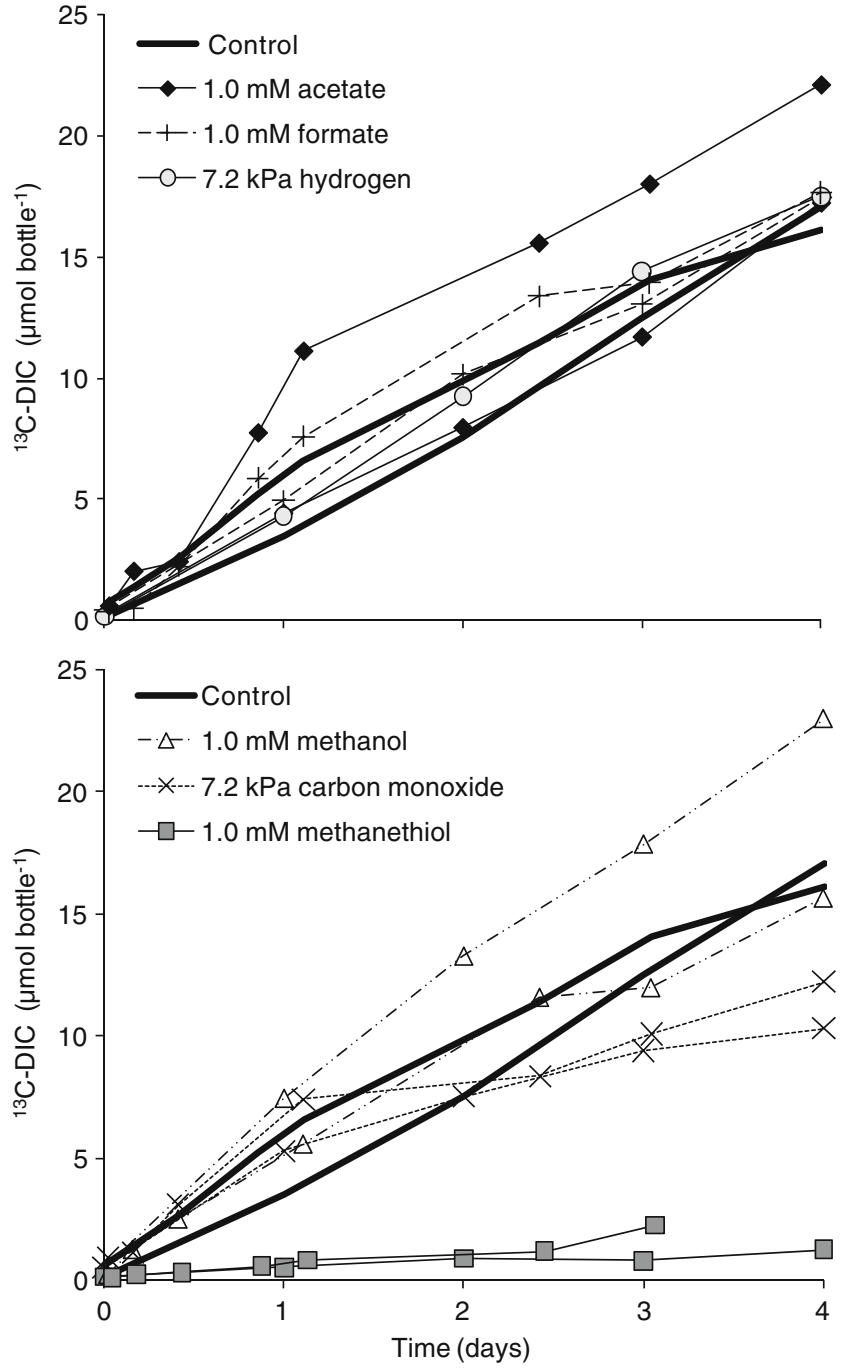

Fig. $1{ }^{13} \mathrm{C}$-DIC production in time, during 4-day batch incubations, in the absence (control) or in the presence of one candidate-IEC. The bottles contained $30 \mathrm{~mL}$ biomass suspension from the enrichment bioreactor and initially $0.16( \pm 0.01) \mathrm{MPa}{ }^{13} \mathrm{CH}_{4}, 15( \pm 1) \mathrm{mM}$ sulfate and $0.2( \pm 0.1) \mathrm{mM}$ sulfide

\section{Results}

Incubations

The ${ }^{13} \mathrm{C}$-DIC production is taken as a measure for ${ }^{13} \mathrm{CH}_{4}$ oxidation because the percentage ${ }^{13} \mathrm{C}$ in DIC produced from other (not ${ }^{13} \mathrm{C}$-enriched) sources is only around $1.1 \%$, while the ${ }^{12} \mathrm{C}$-DIC production (Fig. 2a) did not even exceed the ${ }^{13} \mathrm{C}$-DIC production (Fig. 1) in any of the incubations. The sulfide production was taken as a measure for SR, which was in all incubations coupled to the sulfate removal (Fig. 2b).

Fig. 2 a ${ }^{12}$ Carbon, $\mathbf{b}$ sulfur, and $\mathbf{c}$ reduction equivalent balances over 4-day batch incubations in the absence (control) or in the presence of one candidate-IEC. The $35-\mathrm{mL}$ bottles contained $30 \mathrm{~mL}$ biomass suspension from the enrichment bioreactor and initially $0.16( \pm 0.01)$ $\mathrm{MP}_{\mathrm{a}}{ }^{13} \mathrm{CH}_{4}, 15( \pm 1) \mathrm{mM}$ sulfate, and $0.2( \pm 0.1) \mathrm{mM}$ sulfide
A

$\square^{12} \mathrm{C}$-methane production
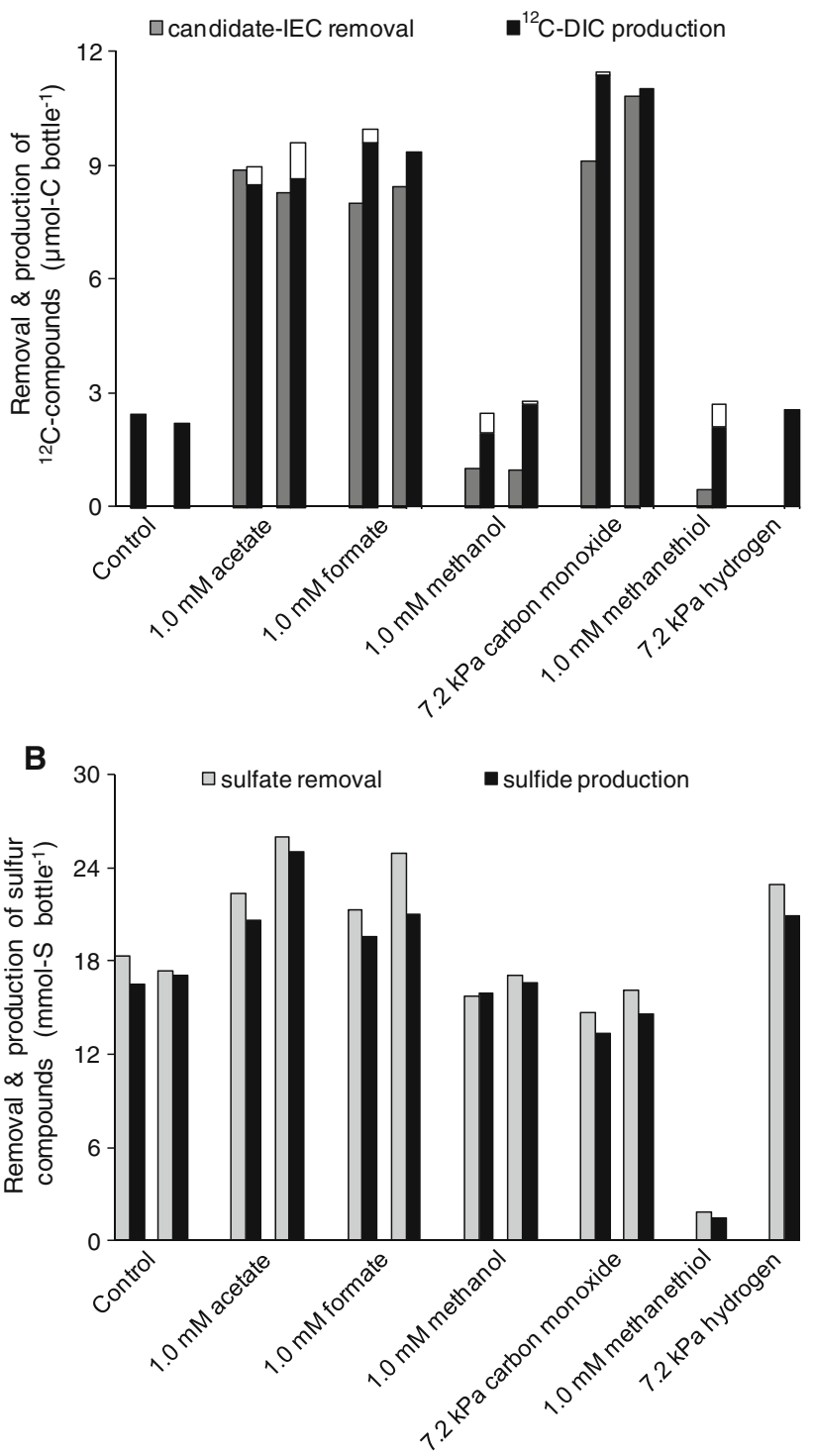

C $\begin{array}{ll}\square \text { candidate-IEC oxidation } & \square{ }^{12} \mathrm{C} \text {-methane production } \\ { }^{13} \mathrm{C} \text {-methane oxidation } & \square \text { sulfate reduction }\end{array}$

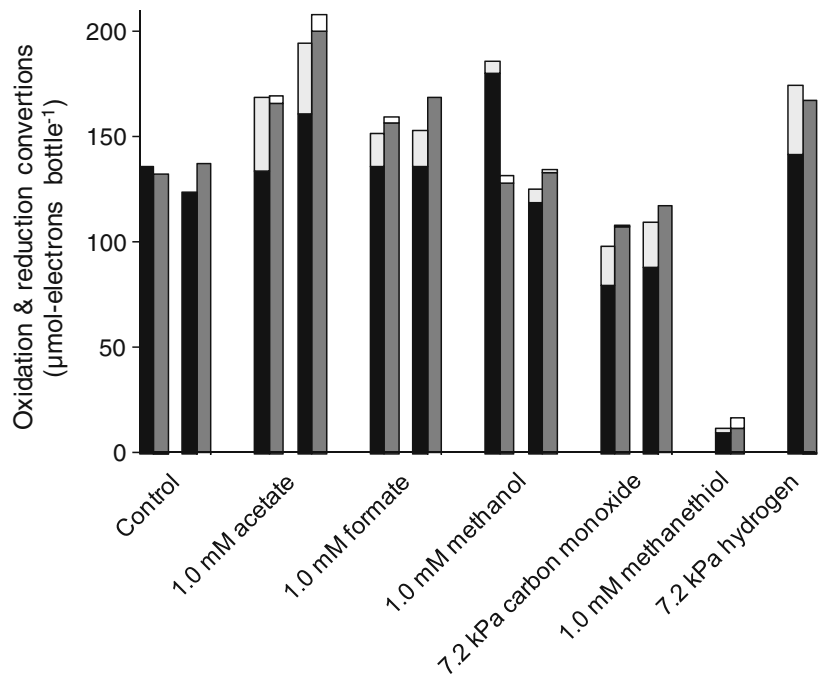


In the absence of candidate-IECs (controls), there was a linear accumulation of ${ }^{13} \mathrm{C}$-DIC during the 4-day incubation (Fig. 1); this ${ }^{13} \mathrm{CH}_{4}$ oxidation was coupled to SR (Fig. 2c), according to the stoichiometry of Eq. 1.

In the presence of acetate, formate, methanol, or hydrogen, there was also a linear accumulation of ${ }^{13} \mathrm{C}$ DIC (Fig. 1), the rates (3.9-5.7 $\mu$ mol bottle ${ }^{-1}$ day $^{-1}$ ) were comparable with the rates without a candidate-IEC (3.9 and $4.2 \mu \mathrm{mol}$ bottle ${ }^{-1} \mathrm{day}^{-1}$ ). In the incubations with carbon monoxide, the ${ }^{13} \mathrm{C}$-DIC production rate was slightly lower (2.7 and $3.0 \mu \mathrm{mol}$ bottle $\mathrm{e}^{-1} \mathrm{day}^{-1}$ ) and methanethiol completely inhibited ${ }^{13} \mathrm{C}$-DIC production.

Some acetate $(8.8$ and $8.3 \mu \mathrm{mol}-\mathrm{C})$, formate $(8.0$ and $8.4 \mu$ mol-C), and carbon monoxide (9.1 and $10.8 \mu$ mol-C) were being removed during the 4-day incubation. Figure $2 \mathrm{a}$ shows that the removal of these candidate-IECs was coupled to ${ }^{12} \mathrm{C}$-DIC production and not ${ }^{12} \mathrm{CH}_{4}$ production, indicating complete oxidation. Methanol (1.0 and $1.0 \mu$ mol-C bottle $\left.{ }^{-1}\right)$ and methanethiol $\left(0.4 \mu\right.$ mol-C bottle $\left.{ }^{-1}\right)$ were hardly removed. All incubations showed some (up to $2.6 \mu \mathrm{mol}$ bottle ${ }^{-1}$ ) background ${ }^{12} \mathrm{C}$-DIC production, likely released from the inoculate.

Figure 2c compares oxidation conversions with reduction conversions. In the presence of acetate, formate, carbon monoxide, and hydrogen more sulfate was reduced than ${ }^{13} \mathrm{CH}_{4}$ oxidized. This additional SR was coupled to the oxidation of candidate-IECs. Therefore, $\mathrm{CH}_{4}$, acetate, formate, carbon monoxide, and hydrogen were all used as electron donor for SR by the enrichment, although the oxidation of ${ }^{13} \mathrm{CH}_{4}$ was, in all incubations, dominant over the oxidation of candidate-IECs. Both SR and ${ }^{13} \mathrm{CH}_{4}$ oxidation were inhibited by the presence of methanethiol.

\section{Thermodynamic calculations}

Table 2 presents the concentrations of candidate-IECs at which their production, under the applied experimental conditions, is no longer thermodynamically possible. To obtain maximum concentrations, the highest measured $\mathrm{CH}_{4}$ partial pressure $(0.16 \mathrm{MPa}), \mathrm{HS}^{-}$concentration $(1 \mathrm{mM})$ and $\mathrm{HCO}_{3}{ }^{-}$concentrations $(1 \mathrm{mM})$ were used for the calculations. Only for the calculation of the maximum $\mathrm{H}_{2}$ partial pressure, the lowest $\mathrm{HCO}_{3}{ }^{-}$concentration $(0.2 \mathrm{mM})$ was used. The theoretical maximum concentration for the production of each candidateIEC was always at least 1,000 times lower than the actual concentration measured at the end of the experiment.

\section{Discussion}

Exclusion of candidate-IECs

This research shows that acetate, formate, methanol, carbon monoxide, and hydrogen can be excluded as sole IEC in AOM coupled to SR by an enrichment composed of ANME2a and bacteria mainly belonging to Deltaproteobacteria and Flavobacteriales. The ${ }^{13} \mathrm{CH}_{4}$ oxidation rates in the presence of these compounds were not or hardly lower than in the controls (Fig. 1). Moreover, during the 4-day incubations, the concentrations of these candidate-IECs were at least $1,000 \times$ higher than the candidate-IEC concentrations at which no more Gibbs free energy can be conserved from their production from $\mathrm{CH}_{4}$ at the applied conditions (Table 2). Nauhaus et al. $(2002,2005)$ already showed that acetate, formate, methanol, carbon monoxide, methylamines, and hydrogen are unlikely IECs in AOM coupled to SR by the ANME-2/bacteria community in Hydrate Ridge sediment because the SR activity on those compounds was lower than on $\mathrm{CH}_{4}$. In Black Sea microbial mats, the SR activity with acetate was also lower than with methane, but with hydrogen and formate this was not the case, which was likely due to the rapid enrichment of SRB not involved in AOM (Nauhaus et al. 2005). Possibly the carbon monoxide concentration (10 kPa CO) used by Nauhaus et al. (2005) was inhibitory for sulfate reduction or the candidate-IECs were consumed by methanogens or homoacetogens. By also assessing the ${ }^{13} \mathrm{CH}_{4}$ oxidation rate (Fig. 1), the ${ }^{12} \mathrm{CH}_{4}$ production (Fig. $2 \mathrm{a}$ ), ${ }^{12} \mathrm{C}$ DIC production (Fig. 2a), and the candidate-IEC consumption (Fig. 2a and c), those possibilities can be excluded in this study for acetate, formate, methanol, carbon monoxide, and hydrogen.

Inhibition by carbon monoxide and methanethiol

${ }^{13} \mathrm{CH}_{4}$ oxidation was slightly hampered by carbon monoxide and completely inhibited by methanethiol (Fig. 1), both
Table 2 The concentration of candidate interspecies electron carriers (IECs) at which their production from $\mathrm{CH}_{4}$ is no longer thermodynamically possible $\left(\Delta G^{\prime}=0\right)$ at $0.16 \mathrm{MPa}$ $\mathrm{CH}_{4}, 0.2 \mathrm{mM} \mathrm{HCO}_{3}^{-}$(for $\mathrm{H}_{2}$ ) or $1 \mathrm{mM} \mathrm{HCO}_{3}^{-}$(of the other potential-IECs), $1 \mathrm{mM} \mathrm{HS}^{-}$, $30{ }^{\circ} \mathrm{C}$, and a $\mathrm{pH}$ of 7

\begin{tabular}{lll}
\hline IEC & IEC concentration at which $\Delta G_{\text {IEC production }}=0$ & IEC concentration on day 4 \\
\hline Acetate & $3.8 \times 10^{-9} \mathrm{M}$ & $8.5 \times 10^{-4}, 8.6 \times 10^{-4} \mathrm{M}$ \\
Formate & $1.0 \times 10^{-8} \mathrm{M}$ & $7.3 \times 10^{-4}, 7.2 \times 10^{-4} \mathrm{M}$ \\
Methanol & $1.8 \times 10^{-15} \mathrm{M}$ & $9.3 \times 10^{-4}, 9.3 \times 10^{-4} \mathrm{M}$ \\
Carbon monoxide & $8.4 \times 10^{-10} \mathrm{kPa}$ & $4.9,4.4 \mathrm{kPa}$ \\
Methanethiol & $8.4 \times 10^{-12} \mathrm{M}$ & $9.9 \times 10^{-4} \mathrm{M}$ \\
Hydrogen & $6.6 \times 10^{-4} \mathrm{kPa}$ & $3.2 \mathrm{kPa}$ \\
\hline
\end{tabular}


compounds have been reported to be toxic. Carbon monoxide hampered SR by sulfate-reducing sludge at a concentration of $5 \%$ or higher (van Houten et al. 1995), and sulfate reducers used only methyl sulfides as substrate at low concentrations $(<10 \mu \mathrm{M}$; Kiene et al. 1986). If these compounds would be produced in situ, the concentrations would remain much lower due to simultaneous consumption, therefore toxic effects would be less profound. Because methanethiol inhibited AOM, it can therefore not be excluded as IEC in AOM coupled to SR. Moran et al. (2007) also reported an inhibition of AOM by methanethiol. If electrons would be transferred via methanethiol, sulfate reducers would be able to utilize these compounds; however that did not occur (Fig. 2b). Possibly, the sulfate reducers were intoxicated by methanethiol.

\section{Local concentration of candidate-IECs}

Many of the candidate-IECs tested were consumed (Fig. 2a, c), which can result in a concentration gradient within the biomass flocks. Therefore, the concentration near the responsible organism can be lower than in the bulk liquid. A big difference between the concentration in the bulk liquid at the concentration near the organism mediating AOM is not expected though because the reactor suspension was well mixed (orbital shaker at $100 \mathrm{rpm}$ ), the biomass flocks were small (0.1 mm; Meulepas et al. 2009), and the candidate-IEC consumption rates were low $\left(<4 \mu \mathrm{mol}\right.$ bottle $^{-1}$ day $\left.^{-1}\right)$.

\section{Syntrophy between ANME and SRB}

The reason that the addition of a candidate-IEC does not affect $\mathrm{AOM}$ and SR might be the involvement of more than one intermediate in AOM coupled to SR (Valentine and Reeburgh 2000; Stams and Plugge 2009). Other theories for the shuttling of electrons between ANME and SRB are that reduction equivalents are transferred via extracellular redox shuttles (Widdel and Rabus 2001; Wegener et al. 2008) or via membrane-bound redox shuttles or so-called "nanowires" (Reguera et al. 2005; Stams et al. 2006; Stams and Plugge 2009; Thauer and Shima 2008; Wegener et al. 2008). The extracellular redox shuttle theory requires the shuttle to be transported back to the ANME after donating the electrons to the SRB, giving rise to an additional loss in Gibbs free energy change available for the microorganisms, due to the concentration gradients between the syntrophic partners. The membrane-bound redox shuttles require the ANME and SRB to make direct physical contact, which is not always the case (Michaelis et al. 2002; Knittel et al. 2005; Orphan et al. 2002; Treude et al. 2005; Jagersma et al. 2009). However, Nielsen et al. (2010) showed that electrical currents in marine sediments coupled spatially separated biogeochemical processes, presumably trough nanowires. Such mechanism might also be responsible for interspecies electron transfer in AOM coupled to SR.

At in situ conditions there is only $-22.35 \mathrm{~kJ} \mathrm{~mol}^{-1}$ available for AOM coupled to SR (Harder 1997). Methanogenic archaea and sulfate-reducing bacteria have been shown to require a free energy change under physiological conditions of at least -10 and $-19 \mathrm{~kJ} \mathrm{~mol}^{-1}$, respectively, to support their metabolism in situ (Hoehler et al. 2001; Dale et al. 2006). Therefore, the in situ free energy change of AOM coupled to SR is probably not sufficiently large to fuel the energy metabolism of two microorganisms in tandem (Schink 1997; Thauer and Shima 2008). Further research should also consider the possibility that one microorganism is responsible for AOM coupled to SR.

\section{Alternative electron donors}

The enrichment was able to utilize acetate, formate, methanol, carbon monoxide, and hydrogen as electron donor for SR (Fig. 2c), although the enrichment was not fed with any other electron donor and carbon source than $\mathrm{CH}_{4}$ for 512 days (Meulepas et al. 2009). Prior to this, the enrichment was additionally fed with small amounts of acetate $\left(70 \mu \mathrm{mol} \mathrm{L}^{-1} \mathrm{day}^{-1}\right)$ for a period of 330 days. Possibly, the sulfate reducers involved in AOM coupled to SR are capable of utilizing acetate, formate, methanol, carbon monoxide, and hydrogen as alternative electron donors for the IEC or $\mathrm{CH}_{4}$. If this would be the case, those microorganisms could be enriched on those alternative substrates instead of on $\mathrm{CH}_{4}$. Another explanation is that other SRB, not involved in AOM coupled to SR, survived the enrichment period. This hypothesis would require inactive SRB to become active within the 4-day duration of the experiment, which is a rather short time span.

Acknowledgments This work was part the Anaerobic Methane Oxidation for Sulfate Reduction project supported by the Dutch ministries of Economical affairs, Education, culture and science, and Environment and special planning as part their EET program and was cofunded by King Abdullah University of Science and Technology through the SOWACOR project.

Open Access This article is distributed under the terms of the Creative Commons Attribution Noncommercial License which permits any noncommercial use, distribution, and reproduction in any medium, provided the original author(s) and source are credited.

\section{References}

Alperin MJ, Hoehler TM (2009) Anaerobic methane oxidation by archaea/sulfate-reducing bacteria aggregates: 1 . Thermodynamic and physical constraints. Am J Sci 309:869-957

Barnes R, Goldberg E (1976) Methane production and consumption in anoxic marine sediments. Geology 4:297-300 
Boetius A, Ravenschlag K, Schubert CJ, Rickert D, Widdel F, Gieseke A, Amann R, Jørgensen BB, Witte U, Pfannkuche O (2000) A marine microbial consortium apparently mediating anaerobic oxidation of methane. Nature 407:623-626

Dale AW, Regnier P, van Cappellen P (2006) Bioenergetic controls on anaerobic oxidation of methane (AOM) in coastal marine sediments: a theoretical analysis. Am J Sci 306:246-294

DeLong EF (2000) Resolving a methane mystery. Nature 407:577579

Hallam SJ, Girguis PR, Preston CM, Richardson PM, DeLong EF (2003) Identification of methyl coenzyme $\mathrm{M}$ reductase A (mcrA) genes associated with methaneoxidizing Archaea. Appl Environ Microbiol 69:5483-5491

Hallam SJ, Putnam N, Preston CM, Detter JC, Rokhsar D, Richardson PM, DeLong EF (2004) Reverse methanogenesis: testing the hypothesis with environmental genomics. Science 305:1457-1462

Harder J (1997) Anaerobic methane oxidation by bacteria employing ${ }^{14} \mathrm{C}$-methane uncontaminated with ${ }^{14} \mathrm{C}$-carbon monoxide. Mar Geol 137:13-23

Hinrichs K-U, Boetius A (2002) The anaerobic oxidation of methane: new insights in microbial ecology and biogeochemistry. In: Ocean Margin Systems. Wefer G, Billet D, Hebbeln D, Jørgensen BB, Schlüter M, van Weering T (eds). Heidelberg, Germany: SpringerVerlag, pp. $457-477$

Hinrichs K-U, Hayes JM, Sylva SP, Brewer PG, DeLong EF (1999) Methane-consuming archaebacteria in marine sediments. Nature 398:802-805

Hinrichs K-U, Summons RE, Orphan V, Sylva SP, Hayes JM (2000) Molecular and isotopic analyses of anaerobic methane-oxidizing communities in marine sediments. Org Geochem 31:16851701

Hoehler TM, Alperin MJ, Albert DB, Martens CS (1994) Field and laboratory studies of methane oxidation in an anoxic marine sediment: evidence for a methanogen-sulfate reducer consortium. Glob Biogeochem Cycles 8:451-463

Hoehler TM, Alperin MJ, Albert DB, Martens CS (2001) Apparent minimum free energy requirements for methanogenic Archaea and sulfate-reducing bacteria in an anoxic marine sediment. FEMS Microbiol Ecol 38:33-41

Jagersma CG, Meulepas RJW, Heikamp-de Jong I, Gieteling J, Klimiuk A, Schouten S, Sinninghe Damsté JS, Lens PNL, Stams AJM (2009) Microbial diversity and community structure of a highly active anaerobic methane oxidizing sulfate-reducing enrichment. Environ Microbiol 11:3223-3232

Kiene RP, Oremland RS, Catena A, Miller LG, Capone DG (1986) Metabolism of reduced methylated sulfur compounds in anaerobic sediments and by a pure culture of an estuarine methanogen. Appl Environ Microbiol 52:1037-1045

Knittel K, Lösekann T, Boetius A, Kort R, Amann R (2005) Diversity and distribution of methanotrophic archaea at cold seeps. Appl Environ Microbiol 71:467-479

Krüger M, Meyerdierks A, Glöckner FO, Amann R, Widdel F, Kube M, Reinhardt R, Kahnt J, Böcher R, Thauer RK, Shima S (2003) A conspicuous nickel protein in microbial mats that oxidize methane anaerobically. Nature 426:878-881

Martens CS, Berner RA (1974) Methane production in the interstitial waters of sulfate-depleted marine sediments. Science 185:11671169

Meulepas RJW, Jagersma CG, Gieteling J, Buisman CJN, Stams AJM, Lens PNL (2009) Enrichment of anaerobic methanotrophs in a sulfate-reducing membrane bioreactor. Biotechnol Bioeng 104 (3):458-470

Meulepas RJW, Jagersma CG, Zhang Y, Petrillo M, Cai H, Buisman CJN, Stams AJM, Lens PNL (2010) Trace methane oxidation and the methane-dependency of sulfate reduction in anaerobic granular sludge. FEMS Microbiol Ecol 72:261-271
Meyerdierks A, Kube M, Kostadinov I, Teeling H, Glöckner FO, Reinhardt R, Amann R (2010) Metagenome and mRNA expression analyses of anaerobic methanotrophic archaea of the ANME-1 group. Environ Microbiol 12:422-439

Michaelis W, Seifert R, Nauhaus K, Treude T, Thiel V, Blumenberg M, Knittel K, Gieseke A, Peterknecht K, Pape T, Boetius A, Amann R, Jørgensen BB, Widdel F, Peckmann J, Pimenov NV, Gulin MB (2002) Microbial reefs in the Black sea fueled by anaerobic oxidation of methane. Science 297:1014-1015

Moran JJ, Beal EJ, Vrentas JM, Orphan VJ, Freeman KH, House CH (2007) Methyl sulfides as intermediates in the anaerobic oxidation of methane. Environ Microbiol 10:162-173

Nauhaus K, Boetius A, Krüger M, Widdel F (2002) In vitro demonstration of anaerobic oxidation of methane coupled to sulphate reduction in sediment from a marine gas hydrate area. Environ Microbiol 4:296-230

Nauhaus K, Treude T, Boetius A, Krüger M (2005) Environmental regulation of the anaerobic oxidation of methane: a comparison of ANME-1 and ANME-2 communities. Environ Microbiol 71:98-106

Nauhaus K, Albrecht M, Elvert M, Boetius A, Widdel F (2007) In vitro cell growth of marine archaeal-bacterial consortia during anaerobic oxidation of methane with sulfate. Environ Microbiol 9 (1):187-196

Nielsen LP, Risgaard-Petersen N, Fossing H, Christensen PB, Sayama M (2010) Electric currents couple spatially separated biogeochemical processes in marine sediment. Nature 463: 1071-1074

Niemann H, Lösekann T, de Beer D, Elvert M, Nadalig T, Knittel K, Amann R, Sauter EJ, Schlüter M, Klages M, Foucher JP, Boetius A (2006) Novel microbial communities of the Haakon Mosby mud volcano and their role as a methane sink. Nature 443:854 858

Orcutt B, Meile C (2008) Constraints on mechanisms and rates of anaerobic oxidation of methane by microbial consortia: processbased modeling of ANME-2 archaea and sulfate-reducing bacteria interactions. Biogeosciences Discuss 5:1933-1967

Orphan VJ, House CH, Hinrichs K-U, McKeegan KD, DeLong EF (2001) Methane-consuming archaea revealed by directly coupled isotopic and phylogenetic analysis. Science 293:484-487

Orphan VJ, House CH, Hinrichs K-U, McKeegan KD, DeLong EF (2002) Multiple archaeal groups mediate methane oxidation in anoxic cold seep sediments. PNAS 99:7663-7668

Reeburgh WS (1976) Methane consumption in Cariaco Trench waters and sediments. Earth Planet Sci Lett 28:337-344

Reguera G, McCarthy KD, Metha T, Nicoll JS, Tuominen MT, Lovley DR (2005) Extracellular electron transfer via microbial nanowires. Nature 435:1098-1101

Schink B (1997) Energetics of syntrophic cooperation in methanogenic degradation. Microbiol Mol Biol Rev 61:262-280

Shigematsu T, Tang Y, Kobayashi T, Kawaguchi H, Morimura S, Kida K (2004) Effect of dilution rate on metabolic pathway shift between aceticlastic and nonaceticlastic methanogenesis in chemostat cultivation. Appl Environ Microbiol 70(7):40484052

Sipma J, Meulepas RJW, Parshina SN, Stams AJM, Lettinga G, Lens PNL (2004) Effect of carbon monoxide, hydrogen and sulfate on thermophilic $\left(55^{\circ} \mathrm{C}\right)$ hydrogenogenic carbon monoxide conversion in two anaerobic bioreactor sludges. Appl Microbiol Biotechnol 64 (3):421-428

Sørensen KB, Finster K, Ramsing NB (2001) Thermodynamic and kinetic requirements in anaerobic methane oxidizing consortia exclude hydrogen, acetate, and methanol as possible electron shuttles. Microb Ecol 42:1-10

Stams AJM, Plugge CM (2009) Electron transfer in syntrophic communities of anaerobic bacteria and archaea. Nature Microbiol Rev 7:568-577 
Stams AJM, de Bok FA, Plugge CM, van Eekert MH, Dolfing J, Schraa G (2006) Exocellular electron transfer in anaerobic microbial communities. Environ Microbiol 8:371-382

Thauer RK, Shima S (2008) Methane as fuel for anaerobic organisms. Ann NY Acad Sci 1125:158-170

Thauer RK, Jungermann K, Decker K (1977) Energy conservation in chemotrophic anaerobic bacteria. Bacteriol Rev 41:100-180

Treude T, Krüger M, Boetius A, Jørgensen BB (2005) Environmental control on anaerobic oxidation of methane in the gassy sediments of Eckernförde Bay (German Baltic). Limnol Oceanogr 50:17711786

Valentine DL, Reeburgh WS (2000) New perspectives on anaerobic methane oxidation. Environ Microbiol 2:477-484

van den Bosch PLF, Fortuny-Picornell M, Janssen AJH (2009) Effects of methanethiol on the biological oxidation of sulfide at natron-alkaline conditions. Environ Sci Technol 43:453459 van Houten RT, van der Spoel H, van Aelst AC, Hulshoff Pol LW, Lettinga $G$ (1995) Biological sulfate reduction using synthesis gas as energy and carbon source. Biotechnol Bioeng 50:136-144

Wegener G, Niemann H, Elvert M, Hinrichs K-U, Boetius A (2008) Assimilation of methane and inorganic carbon by microbial communities mediating the anaerobic oxidation of methane. Environ Microbiol 10:2287-2298

Weijma J, Stams AJM, Hulshoff Pol LW, Lettinga G (2000) Thermophilic sulfate reduction and methanogenesis with methanol in a high rate anaerobic reactor. Biotechnol Bioenring 67(3):354-363

Widdel F, Bak F (1992) Gram negative mesophilic sulphate-reducing bacteria. In: Balows A, Trüper HG, Dworkin M, Harder W, Schleifer K-H (eds) The prokaryotes. Springer, New York, pp 3352-3378

Widdel F, Rabus R (2001) Anaerobic biodegradation of saturated and aromatic hydrocarbons. Curr Opin Biotechnol 12:259-276

Zehnder AJB, Brock TD (1980) Anaerobic methane oxidation: occurrence and ecology. Appl Environ Microbiol 39:194-204 